\title{
МЕДИЧНЕ ЦИТУВАННЯ: \\ ПУТІВНИК NLМ ДЛЯ АВТОРІВ, РЕДАКТОРІВ І ВИДАВЦІВ
}

\author{
К.Петріас (автор), Д.Вендлінг (редактор)
}

Джерело: Patrias K, author; Wendling D, editor. Citing Medicine: The NLM Style Guide for Authors, Editors, and Publishers [Internet]. 2nd edition. Bethesda (MD): National Library of Medicine (US); 2007 -.

Bookshelf ID: NBK7282

Available from:

http://www.ncbi.nlm.nih.gov/books/NBK7256

\section{Розділ 4. Наукові та технічні доповіді}

Приналежність автора / редактора до звіту (необов'язково)

Загальні правила для приналежності автора

- Позначте у приналежності до звіту виконавчу організацію, окрім випадків, коли виконавча організація також є видавцем

- Почніть з відділу і назви установи, після чого необхідно вказати місто і штат / канадську провінцію / країну

- Використовуйте коми для розділення частини адрес

- Поміщайте приналежність у дужки, наприклад, (Department of Psychology, University of Pittsburgh, Pittsburgh, PA)

- Введіть інформацію про адресу після останнього названого автора, окрім випадків, коли автори представляють більш ніж одну організацію; див. Автори з більш ніж однієї організації нижче

- Відділяйте приналежність від автора пробілом

- Після позначення приналежності необхідно поставити кому, яку необхідно помістити після дужки. У випадку, якщо приналежність стосується останнього автора, необхідно поставити крапку.

Автори з більш ніж однісї організації

Звіти можуть бути спільними зусиллями більш ніж однієї організації.

- Використовуйте крапку з комою та пробіл для відокремлення груп авторів 3 різних організацій

- Включіть адресу кожного автора або групи авторів

Приклад:

Thompson LA, Chhikara RS (School of Natural and Applied Sciences, University of Houston, Clear Lake, TX); Conklin J (Lyndon B. Johnson Space Center, Houston, TX).

Спеціальні правила для приналежністі автора

Зазначення адреси електронної пошти

- Після штату США і провінції Канади або країни автора необхідно поставити кому та пробіл

- Адресу електронної пошти необхідно зазначити у тому вигляді, в якому вона з'являється у публікації

- Не ставте після адреси електронної пошти крапку

- Помістіть адресу електронної пошти у дужках для приналежності автора

Приклад:

de la Cruz FF (Mental Retardation and Developmental Disabilities Branch, National Institute of Child Health and Human Development, Bethesda, MD.delacruz@nichd.nih.gov).

Скорочення у причетності

- Скорочуйте загальновживані слова у приналежності за потреби. Наприкінці скорочених слів ставте крапку.

о Приклади:

- Acad. для Academy

- Assoc. для Association

- Co. для Company

- Coll. для College

- Corp для Corporation

- Dept. для Department

- Div. для Division

- Inst. для Institute або Institution

- Soc. для Society

- Univ. для University

o Див. у Додаток C більше загальновживаних скорочень англійських слів.

- Скорочуйте назви американських штатів і провінцій Канади, використовуючи офіційні дволітерні скорочення. Перелік останніх дивись у Додаток Е.

- Скорочуйте назви країн, що знаходятсься за межами США і Канади за допомогою дволітерного ISO кода країни за потреби. У Додаток D дивись коди відповідних країн. 
- Будьте послідовні. Якщо ви скорочуйте слово в одному посиланні в списку літератури, то те ж саме слово необхідно скорочувати у всіх наступних посиланнях.

Назви організацій для приналежності неанглійською мовою

- Позначте у приналежності до звіту виконавчу організацію, окрім випадків, коли виконавча організація також $\epsilon$ видавцем

- Інформацію щодо приналежності необхідно позначати після останнього автора, окрім випадків, коли автори представляють більш ніж одну організацію; див. Автори з більш ніж однієі організації нижче

- Почніть 3 відділу і назви установи, після чого необхідно вказати місто і дволітерне скорочення штату або канадської провінції (див. Додаток E), назву країни або ISO код країни (див. Додаток D) для неамериканських країн. Використовуйте коми для відокремлення частин адрес. Помістіть адреси у дужки.

- Для не англійських назв організацій ім'я необхідно вказати мовою оригіналу буквами латинського алфавіту (в першу чергу європейських мов, таких як французька, німецька, іспанська, італійська, шведська і т.д.)

o Carpentier AF (Service de Neurologie, Hopital de la Salpetriere, Paris, France), Moreno Perez D (Unidad de Infectologia e Inmunodeficiencias, Departamento de Pediatria, Hospital Materno-Infantil Carlos Haya, Malaga, Spain).

o Marubini E (Istituto di StatisticaMedica e Biometria, UniversitadegliStudi di Milano, Milan, Italy), Rebora P, Reina G.

- Назви кирилицею, грецькою, арабською, на івриті або корейською мовами необхідно представити буквами латинського алфавіту. Авторитетний ресурс для латинізації $\underline{A L A-L C}$ Romanization Tables.

o Barbulescu

M

(ClinicaChirurgicala, Spitalul Clinic Coltea, Bucarest, Romania), Burcos $\mathrm{T}$, Ungureanu $\mathrm{CD}$, Zodieru-Popa I.

o Grudinina NA (Institute of Experimental Medicine, Russian Academy of Medical Sciences, St. Petersburg, Russia), Golubkov VI, Tikhomirova OS, Brezhneva TV, Hanson KP, Vasilyev VB, Mandelshtam MY.

- Назви організацій, що представлені символьними мовами (китайська, японська), необхідно перекласти

o Susaki K (First Department of Internal Medicine, Faculty of Medicine, Kagawa University, Takamatsu, Japan), Bandoh S, Fujita J, Kanaji N, Ishii T, Kubo A, Ishida T.

- Діакритичні знаки, акценти та спеціальні символи у назвах, необхідно ігнорувати. Це правило ігнорує деякі умовні позначення у неанг- лійських мовах за для спрощення правил публікації англійською мовою.

о Літери, позначені діакритичними знаками та наголосами, необхідно вказувати без спеціальних позначень

- $\AA$ позначайте як $\mathrm{A}$

- Ø позначайте як $\mathrm{O}$

- С̧ позначайте як $\mathrm{C}$

- Ł позначайте як L

- à nозначайте як a

- $\mathrm{g}$ позначайте як $\mathrm{g}$

- $\tilde{\mathrm{n}}$ позначайте як $\mathrm{n}$

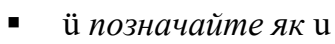

o Дві або більше букв, що надруковані як єдине ціле (ліговані букви), необхідно позначати двома окремими літерами

- æ позначайте як ае

- œ позначайте як ое

- Використовуйте англійську форму для назв міст і країн, коли це можливо. Наприклад, Vienna для Wien i Spain для Espana. Однак, назва, як вони позначена у публікації, також може бути використана.

Назви міст і країн не англійською мовою

- Використовуйте англійську форму для назв міст і країн, коли це можливо. Однак, назва в тому вигляді, в якому вона представлена у публікації, завжди може бути використана.

o Moskva позначайте як Moscow

o Wien позначайте як Vienna

- Italia позначайте як Italy

o Espana позначайте як Spain

Автори з більш ніж однісї організації

Звіти можуть бути спільними зусиллями більш ніж однієї організації.

- Використовуйте крапку з комою та пробіл для відокремлення груп авторів 3 різних організацій

- Включіть адресу кожного автора або групи авторів

Приклад:

Thompson LA, Chhikara RS (School of Natural and Applied Sciences, University of Houston, Clear Lake, TX); Conklin J (Lyndon B. Johnson Space Center, Houston, TX).

Приклади для приналежності автора

Стандартний звіт, написаний виконавчою організацісю та опублікований організацісю-спонсором

Sontag ED (Department of Mathematics, Rutgers University, New Brunswick, NJ). Control of nonlinear systems. Final report 15 Mar 2004-31 Jan 2005. Washington: Army Medical Department (US): 2004. 5 p. Report No.: AFRLSRARTR050271. Contract No.: FA95500410172.

Newberry SJ, editor (Southern California/RAND Evidence-based Practice Center, Los Angeles, CA). Effects of omega-3 fatty acids on lipids and glycemic control in type II diabetes and 
the metabolic syndrome and on inflammatory bowel disease, rheumatoid arthritis, renal disease, systemic lupus erythematosus, and osteoporosis. Rockville (MD): Department of Health and Human Services (US), Agency for Healthcare Research and Quality; 2004 Mar. 145 p. Contract No.: 290-02-0003.

Звіт із зазначенням авторів як виконавчих, так і спонсорських організацій

Thompson LA, Chhikara RS (School of Natural and Applied Sciences, University of Houston, Clear Lake, TX); Conklin J (Lyndon B. Johnson Space Center, Houston, TX). Cox proportional hazards models for modeling the time to onset of decompression sickness in hypobaric environments. Houston (TX): National Aeronautics and Space Administration (US), Lyndon B. Johnson Space Center; 2003 Mar. 39 p. Report No.: NASA/TP-2003210791. Grant No.: NASA 9-1083. Basic funding support provided by the Institute for Space Systems Operations of the University of Houston.

Назва звіту (обов'язково)

Загальні правила назви

- Назву звіту або іншого додатка необхідно навести в тому вигляді, в якому вона представлена в оригінальному документі на мові оригіналу

- 3 великими літерами необхідно позначати тільки перше слово назви, власні імена, відповідні прикметники, акроніми та ініціали

- Використовуйте двокрапку та пробіл, щоб відокремити назву від підзаголовка, окрім випадків, якщо який-небудь інший знак пунктуації (наприклад, знак питання, крапка або знаку оклику) вже стоїть

- Назви не англійською мовою необхідно переводити, якщо це можливо; переклад необхідно поміщати у квадратних дужках

- Наприкінці назви необхідно поставити крапку, за вийнятком тих випадків, коли знак питання або оклику або тип середовища слідують після цього

Спеціальні правила назви

Назви неанглійською мовою

- Назви неанглійськими мовами (в першу чергу європейських мов, таких як французька, німецька, іспанська, італійська, шведська і т.д.) необхідно представити мовою оригіналу буквами латинського алфавіту

o Contreras A, Drabo Y, Shimp L, de Quinteros P, Linares MA. L'operationnalisation a l'echelle des pratiques familiales cles en matiere de sante et de nutrition de l'enfant: le role du changement des comportements. Washington: Agency for International Development (US); 2004 Apr. 40 p. Report No.: PB2005-104459. French..

- Назви зазначені кирилицею, грецькою, арабською, на івриті або корейською мовами необхідно романізувати (представляти латинськими літерами). Авторитетним ресурсум для ро-

манізації є ALA-LC Romanization Tables.

0

Rossiya--1994.

Sotsial'no-demograficheskaya situatsiya. Analiticheskii doklad. Moskow: Rossiiskaya Akademiya Nauk, Institut Sotsial'noekonomicheskikh Problem Narodonaseleniya; 1995. 207 p. Russian.

- Назви символьними мовами (китайська, японська) необхідно романізувати або перекладати. Перекладені назви поміщайте у квадратних дужках.

o Xianggang chuan ran bing tong ji shu zi 1946-2001. Hong Kong: People's Republic of China, Disease Prevention and Control Division, Government of the Hong Kong Special Administrative Region, Department of Health; 2002. 83 p. Chinese.

або

o [Statistics on infectious diseases in Hong Kong, 1946-2001]. Hong Kong: People's Republic of China, Disease Prevention and Control Division, Government of the Hong Kong Special Administrative Region, Department of Health; 2002. 83 p. Chinese.

- Після назви мовою оригіналу або латинізованої назви необхідно надати переклад англійською мовою у квадратних дужках, якщо це можливо

o Contreras A, Drabo Y, Shimp L, de Quinteros P, Linares MA. L'operationnalisation a l'echelle des pratiques familiales cles en matiere de sante et de nutrition de l'enfant: le role du changement des comportements [Operationalizing key family practices for child health and nutrition at scale: the role of behavior change]. Washington: Agency for International Development (US); 2004 Apr. 40 p. Report No.: PB2005-104459. French.

o Rimashevskaya NM, Markov VI. Rossiya-1994. Sotsial'no-demograficheskaya situatsiya. Analiticheskii doklad [Russia--1994. The sociodemographic situation. An analytical report]. Moskow: Rossiiskaya Akademiya Nauk, Institut Sotsial'no-ekonomicheskikh Problem Narodonaseleniya; 1995. 207 p. Russian.

o Xianggang chuan ran bing tong ji shu zi 1946-2001 [Statistics on infectious diseases in Hong Kong, 1946-2001]. Hong Kong: People's Republic of China, Disease Prevention and Control Division, Government of the Hong Kong Special Administrative Region, Department of Health; 2002. 83 p. Chinese.

- Діакритичні знаки, акценти та спеціальні символи у назвах, необхідно ігнорувати. Це правило ігнорує деякі умовні позначення у неанглійських мовах за для спрощення правил публікації англійською мовою.

о Літери, позначені діакритичними знаками та наголосами, необхідно вказувати без спеціальних позначень

- А̊ позначте як $\mathrm{A}$

- Ø позначте як $\mathrm{O}$ 
- С̧ позначте як $\mathrm{C}$

- Ł позначте як L

- à позначте як а

- $\hat{\mathrm{g}}$ позначте як $\mathrm{g}$

- $\tilde{\mathrm{n}}$ позначте як $\mathrm{n}$

- ü позначте як u

o Дві або більше букв, що надруковані як єдине ціле (ліговані букви), необхідно позначати двома окремими літерами

- æ позначте як ае

- œ позначте як ое

Назви більш ніж однісю мовою

Якщо звіт написаний декількома мовами:

- Назву необхідно подати першою мовою, що зазначена на титульній сторінці

- Позначте всі мови публікації після сторінок та будь-які номери звітів, контрактів або грантів

- Наприкінці переліку мов необхідно поставити крапку

Приклад:

Eidgenossische Volkszahlung 1990: die Wohnbevolkerung der Gemeinden. Bern (Switzerland): Bundesamt fur Statistik; 1993. 154 p. German, French, Italian.

Якщо звіт представлена двома або більше рівними мовами, як це часто буває в канадських виданнях:

- Всі назви необхідно подати у тому порядку, в якому вони представлені у тексті зі знаком рівності поміж ними

- Позначте всі мови публікації після сторінок та будь-які номери звітів, контрактів або грантів

- Мови необхідно відокремлювати комою та пробілом

- Наприкінці переліку необхідно поставити крапку

Приклади:

Biotechnology and the health of Canadians: a report from the Canadian Biotechnology Advisory Committee on biotechnology and health innovations; opportunities, challenges, and public policy = Biotechnologie et la sante des Canadiens: rapport du Comite consultatif canadien de la biotechnologie sur la biotechnologie et l'innovation dans le domaine de la sante; aspects prometteurs, de'fis et politique publique. Ottawa $(\mathrm{ON})$ : Canadian Biotechnology Advisory Committee; 2004 Dec. 181 p. English, French.

Euler M. Genitale Verstummelung von Madchen und Frauen: Situationsbericht aus dem Sudan $=$ Female genital mutilation: a report on the present situation in Sudan $=$ Mutilations sexuelles chez les fillettes et les femmes: rapport sur l'etat de la situation au Soudan. Aachen (Germany): Missio Aachen; 2002. 60 p. German, English, French.

- Якщо жодна 3 мов не $\epsilon$ англійською, необхідно після назви навести переклад, якщо це можливо. Переклад необхідно зазначити у квадратних дужках

Eidgenossische Volkszahlung 1990: die Wohnbevolkerung der Gemeinden [Federal population census 1990: the population of communities]. Bern (Switzerland): Bundesamt fur Statistik; 1993. 154 p. German, French, Italian.

Mesle F, Shkol'nikov V, Hertrich V, Vallin J. Tendances recentes de la mortalite par cause en Russie 1965-1994 = Sovremennye tendentsii smertnosti po prichinam smerti v Rossii 1965-1994 [Recent trends in mortality by cause in Russia, 1965-1994]. Paris: Institut National d'Etudes Demographiques; 1996. 140 p. French, Russian.

Назви, що містять грецьку літеру, хімічну формулу, або інший спеціальний символ

- Перше слово назви звіту необхідно починати $з$ великої літери, якщо назва не починається 3 грецької букви, хімічної формули або іншого спеціального символу, які при написанні заголовними літерами можуть втратити свій сенс alpha-Methyldopa sesquihydrate (feed studies).

1,3-dichloro-5,5-dimethylhydantoin: healthbased reassessment of administrative occupational exposure limits.

- Якщо назва звіту містить грецьку букву або будь-який інший символ, що неможливо надрукувати, замініть його словом. Наприклад, $\Omega$ замініть на омега.

Lindane ( $\gamma$-hexachlorocyclohexane): healthbased recommended occupational exposure limit.

або

Lindane (gamma-hexachlorocyclohexane): health-based recommended occupational exposure limit.

- Якщо назва звіту містить надрядкові або підрядкові індекс, які неможливо надрукувати, позначте їх у дужках

Autoradiographic localization of [ $\left.{ }^{125} \mathrm{I}\right]$-ricin in lungs and trachea of mice following an aerosol inhalation exposure.

або

Autoradiographic localization of [(125)I]-ricin in lungs and trachea of mice following an aerosol inhalation exposure.

Приклади для назви звіту

Звіт неанглійською мовою

Contreras A, Drabo Y, Shimp L, de Quinteros $\mathrm{P}$, Linares MA. L'operationnalisation a l'echelle des pratiques familiales cles en matiere de sante et de nutrition de l'enfant: le role du changement des comportements.Washington: Agency for International Development (US); 2004 Apr. 40 p. Report No.: PB2005-104459. French.

Eidgenossische Volkszahlung 1990: die Wohnbevolkerung der Gemeinden.Bern (Switzerland): Bundesamt fur Statistik; 1993. 154 p. German, French, Italian. 


\section{3 перекладом}

Contreras A, Drabo Y, Shimp L, de Quinteros P, Linares MA. L'operationnalisation a l'echelle des pratiques familiales cles en matiere de sante et de nutrition de l'enfant: le role du changement des comportements [Operationalizing key family practices for child health and nutrition at scale: the role of behavior change]. Washington: Agency for International Development (US); 2004 Apr. 40 p. Report No.: PB2005-104459. French.

Eidgenossische Volkszahlung 1990: die Wohnbevolkerung der Gemeinden[Federal population census 1990: the population of communities]. Bern (Switzerland): Bundesamt fur Statistik; 1993. 154 p. German, French, Italian.

Звіт, написаний двома або білыше рівними мовами

Biotechnology and the health of Canadians: a report from the Canadian Biotechnology Advisory Committee on biotechnology and health innovations; opportunities, challenges, and public policy = Biotechnologie et la sante des Canadiens: rapport du Comite Consultatif Canadien de la Biotechnologie sur la biotechnologie et l'innovation dans le domaine de la sante; aspects prometteurs, de fis et politique publique. Ottawa (ON): Canadian Biotechnology Advisory Committee; 2004 Dec. 181 p. English, French.

Euler M. Genitale Verstummelung von Madchen und Frauen: Situationsbericht aus dem Sudan $=$ Female genital mutilation: a report on the present situation in Sudan $=$ Mutilations sexuelles chez les fillettes et les femmes: rapport sur l'etat de la situation au Soudan. Aachen (Germany): Missio Aachen; 2002. 60 p. German, English, French.

3 доданням перекладу

Mesle F, Shkol'nikov V, Hertrich V, Vallin J. Tendances recentes de la mortalite par cause en Russie 1965-1994 = Sovremennye tendentsii smertnosti po prichinam smerti v Rossii 1965-1994 [Recent trends in mortality by cause in Russia, 1965-1994]. Paris: Institut National d'Etudes Demographiques;1996. 140 p. French, Russian.

Назва звіту, що містить грецьку літеру, хімічну формулу, або інший спеціальний символ

Грецькі літери можуть бути заміщені, якщзо спеціальні символи недоступні

Dutch Expert Committee on Occupational Standards. Lindane ( $\gamma$-hexachlorocyclohexane): health-based recommended occupational exposure limit. The Hague (Netherlands): Health Council of the Netherlands; 2001 Dec 6. 124 p.

або

Dutch Expert Committee on Occupational Standards. Lindane (gammahexachlorocyclohexane): health-based recommended occupational exposure limit. The Hague (Netherlands): Health Council of the Netherlands;
2001 Dec 6. 124 p.

Знаки верхнього та нижнього регістру можуть бути поміщені у дужки, якщо символи недоступні

Doebler JA. Autoradiographic localization of $\left[{ }^{125} \mathrm{I}\right]$-ricin in lungs and trachea of mice following an aerosol inhalation exposure. Aberdeen Proving Ground (MD): Army Medical Research Institute of Chemical Defense (US); 1996. 8 p. Report No.: USAMRICD-TR; 96-03.

або

Doebler JA. Autoradiographic localization of [(125)I]-ricin in lungs and trachea of mice following an aerosol inhalation exposure. Aberdeen Proving Ground (MD): Army Medical Research Institute of Chemical Defense (US); 1996. 8 p. Report No.: USAMRICD-TR; 96-03.

Тип носія для звітів (обов'язково)

Загальні правила для типу носія

- Тип носія (мікрофіш, мікрофільм, ультрафіш, мікрокарта і т.д.) слід вказувати після назви (та після типу змісту, якщо він є), коли звіт видається у мікроформі

- Тип носія слід розміщати у квадратних дужках, відокремлюючи ії крапкою після закриття дужок, наприклад, [мікрофіш].

- Додаткова інформація щодо типу носія відповідно до інструкцій представлена нижче

Спеціальні правила для типу носія

Назви, що закінчуються знаками пунктуації, окрім крапки

- Більшість назв звітів закінчуються крапкою. Слова [мікрофіш], [мікрофільм] або [мікрокарта] слід розміщувати перед крапкою

Blood carbon monoxide and hydrogen cyanide concentration in the fatalities of fire and non-fire associated civil aviation accidents, 1991-1998 [microfiche].

- Якщо назва закінчується іншим знаком пунктуації, слова [мікрофіш], [мікрофільм] або [мікрокарта] слід розміщувати попереду даного знаку, а після них ставити крапку

Is peripheral benzodiazepine receptor (PBR) gene expression involved in breast cancer suppression by dietary soybean protein? [microfiche].

Назви неанглійською мовою

- Якщо переклад назви надається, помістіть його після оригінальної мови у квадратних дужках

Travaux scientifiques des chercheurs du service de sante des armees [Scientific works of research workers of the army health service].

- Якщо назва звіту представлена у вигляді у мікроформи (мікрофіш, мікрофільм, мікрокарта і т.д.), тип мікроформи слід розміщати у квадратних дужках після переводу

Untersuchungen zur Abtrennung von Schwermetallen aus Grubenwaessern mittels Mikroorganismen [Investigation of separation of heavy metals 
from mine water by microbes] [microfiche].

\section{Приклади для типу носія}

Звіт у мікроформі

Chaturvedi AK, Smith DR, Canfield DV. Blood carbon monoxide and hydrogen cyanide concentration in the fatalities of fire and non-fire associated civil aviation accidents, 1991-1998 [microfiche]. Final report. Washington: Federal Aviation Administration (US), Office of Aviation Medicine; 2000. 1 microfiche: black \& white, negative, 4 x 6 in.

Видання звітів (обов'язково)

Загальні правила для видання

- Необхідно вказати видання / інформацію, що цитується після назви (тип змісту або тип носія, якщо $є)$, коли звіт видається більш ніж в одному виданні або редакції

- Необхідно скорочувати загальні слова (див. Правила скорочень для видань нижче)

- Великими літерами необхідно позначати тільки перше слово у інформації про видання, власні іменники та власні прикметники

- Номера необхідно виражати арабськими чисельниками. Наприклад: другий як 2й та III як Зй.

- Після інформації про видання необхідно поставити крапку

Правила скорочень для видань

- Загальні слова у інформації про видання, можуть бути скорочені наступним чином:

\begin{tabular}{|c|c|}
\hline Слово & Скорочення \\
\hline edition & ed. \\
\hline abbreviated & abbr. \\
\hline abridged & abr. \\
\hline American & Am. \\
\hline augmented & augm. \\
\hline authorized & authoriz. \\
\hline English & Engl. \\
\hline enlarged & enl. \\
\hline expanded & expand. \\
\hline illustrated & ill. \\
\hline modified & mod. \\
\hline original & orig. \\
\hline reprint(ed) & repr. \\
\hline revised & rev. \\
\hline special & spec. \\
\hline translation & transl. \\
\hline translated & \\
\hline
\end{tabular}

Додаткову інформацію про скорочення див. y ISO 832:1994 - Правила для скорочення бібліографічних термінів.

- Наприкінці скорочених слів, а також всієї інформації про видання необхідно ставити крапку

o 3rd rev. ed.

o 1st Engl. ed.

Спеціальні правила для видання

Правила скорочень для видань

- Загальні слова у інформації про видання, можуть бути скорочені наступним чином:

\begin{tabular}{|c|c|}
\hline Слово & Скорочення \\
\hline edition & ed. \\
\hline abbreviated & abbr. \\
\hline abridged & abr. \\
\hline American & Am. \\
\hline augmented & augm. \\
\hline authorized & authoriz. \\
\hline English & Engl. \\
\hline enlarged & enl. \\
\hline expanded & expand. \\
\hline illustrated & ill. \\
\hline modified & mod. \\
\hline original & orig. \\
\hline reprint(ed) & repr. \\
\hline revised & rev. \\
\hline special & spec. \\
\hline translation & transl. \\
\hline translated & \\
\hline
\end{tabular}

- Додаткову інформацію про скорочення див. y ISO 832:1994 - Правила для скорочення бібліографічних термінів.

- Наприкінці скорочених слів, а також всієї інформації про видання необхідно ставити крапку

o 3rd rev. ed.

o 1st Engl. ed.

Видання 3 позначенням дат

Назви звітів часто мають такі фрази, як "Річний звіт", "Проміжний звіт" та "Підсумковий звіт".

- Якщо такі фрази супроводжуються датою або діапазоном чи дати, включіть ці дати в частину видання

- Дати позначте в будь-якому форматі

- Наприкінці відомостей про дату необ- 
хідно поставити крапку

Приклади:

Final report for July 21, 1989 - June 21, 1990.

Final report. Jan-Nov 1999.

Annual summary 1 Jul 2000-31 Dec 2004.

Final report. May 2002-Mar 2005.

Report for 8 Jan 03-30 Mar 03.

Неанглійські слова для видань

- Інформацію про видання неанглійською мовою необхідно представити латинськими буквами:

лу

о Назву необхідно вказати мовою оригіна-

о Загальні слова у інформації про видання необхідно скорочувати, якщо мова $є$ зрозумілою

о Великими літерами необхідно позначати тільки перше слово та власні іменники, окрім випадків коли дана мова не вимагає написання великими літерами інших слів

o Не зважайте на діакритичні знаки, наголоси і спеціальні символи у словах. Це правило ігнорує деякі умовні позначення у неанглійських мовах за для спрощення правил для публікації англійською мовою.

о Числа або числа словами не потрібно переводити в арабські цифри, як це практикується для англомовних видань. Це допомагає з незнайомою мовою, а також дозволяє уникнути незручних конструкцій.

о Видання необхідно відокремлювати від власне назви пробілом

о Необхідно залишати розділові знаки, що використовувались у інформації про видання

o Наприкінці скорочених слів, а також всієї інформації про видання необхідно ставити крапку

\section{- Приклади:}

Shohan.

Dai 1-han.

Dai 3-pan.

Di 3 ban.

Cai se ban, Xianggang di 1 ban.

Che 6-p`an

- Для визначення видання іншими мовами, нижче наведено короткий перелік неанглійських слів для видань та їх скорочень (n.a. = не скорочується):

\begin{tabular}{|c|c|c|}
\hline Мова & Слово у виданні & Скорочення \\
\hline Данська & oplag & n.a. \\
\hline Голландська & udgave & \\
\hline & editgave & uitg. \\
\hline Фінська & julkaisu & ed. \\
\hline Французька & edition & julk. \\
\hline Німецька & Ausgabe & Ausg. \\
\hline Auflage & Aufl. \\
\hline Грецька & ekdosis & ekd. \\
\hline Італійська & edizione & ed. \\
\hline Норвезька & publikasjon & publ. \\
\hline & utgave & utg. \\
\hline Португальська & edicao & ed. \\
\hline Російська & izdanie & izd. \\
\hline Іспанська & edicion & ed. \\
\hline & publicacion & publ. \\
\hline & upplaga & n.a. \\
\hline
\end{tabular}

Приклади для видання

Звіт 3 виданням

Persing DH. Biomarker development for TLR4 agonists. Annual report.Seattle (WA): CORIXA Corporation; 2004 Oct. 76 p. Contract No.: DAMD17-03-C-0089. Funded by the US Army Medical Research and Materiel Command, Ft. Detrick, MD.

Thomas C, Butler J, Davies M, Johnson R, editors. State injury indicators report: 1999 data. 2nd ed. Atlanta (GA): Centers for Disease Control and Prevention (US), National Center for Injury Prevention and Control; 2004 Feb. 108 p.

National High Blood Pressure Education Program (US). The fourth report on the diagnosis, evaluation, and treatment of high blood pressure in children and adolescents. Rev. ed. Bethesda (MD): National Heart, Lung, and Blood Institute (US); 2005. 48 p. (NIH publication; no. 05-5267). 